\title{
Improving Competitiveness and Fostering Productivity in Spain*
}

\author{
VERÓNICA ESCUDERO \\ International Institute for Labour Studies, INTERNATIONAL LABOUR ORGANIZATION, \\ SWITZERLAND.E-mail: escudero@ilo.org \\ ELVA LÓPEZ MOURELO \\ International Institute for Labour Studies, INTERNATIONAL LABOUR ORGANIZATION, \\ SWITZERLAND. E-mail: lopezmourelo@ilo.org
}

\begin{abstract}
Competitiveness in Spain has deteriorated dramatically over the past decade driven mainly by a decrease in labour productivity. Since the onset of the current crisis, however, there were some signs of recovery in labour productivity, which accompanied by well design policies could lead to a sustainable improvement in competitiveness. The purpose of this paper is to shed light on the main factors that lead to the deterioration in Spain's competitiveness and describe some of the recent developments that lead us to believe that there are early signs of a departure from pre-crisis growth patterns. Finally, the paper discusses a number of policy shortcomings that Spain will need to address in order to attain a sustainable improvement in labour productivity and, therefore, make a structural transformation towards a more balanced economic growth.
\end{abstract}

Keywords: Competitiveness, Labour Productivity, Wage Determination.

\section{Mejorar la competitividad y fomentar la productividad en España}

\begin{abstract}
RESUMEN
La competitividad en España se deterioró drásticamente a lo largo de la última década, motivada principalmente por una caída en la productividad laboral. No obstante, desde el comienzo de la actual crisis económica, han empezado a observarse ciertos signos de recuperación en la productividad laboral que acompañados de las políticas correctas podrían desembocar en una mejora sostenible de la competitividad. El objetivo de este artículo es arrojar luz sobre los principales factores que explicaron el deterioro de la competitividad en España y describir los acontecimientos recientes que nos permiten pensar en una trayectoria diferente de la del crecimiento anterior a la crisis. Finalmente, el artículo presenta una serie de recomendaciones de política que España debería tener en cuenta para alcanzar una mejora sostenible en la productividad laboral y, por lo tanto, lograr una transformación estructural hacia un crecimiento económico más equilibrado.
\end{abstract}

Palabras clave: Competitividad, productividad laboral, determinación salarial.

JEL Classification: J24, J30

\footnotetext{
* The authors would like to thank Steven Tobin for important contributions and Miguel Ángel Malo and Sameer Khatiwada for valuable comments. This paper is a summarized version of Chapter 3 of the report Spain: Quality jobs for a new economy produced by the International Institute for Labor Studies (ILS) of the ILO (see ILO, 2011b).
}

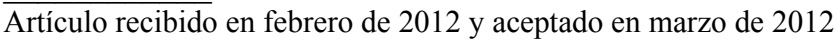

Artículo disponible en versión electrónica en la página www.revista-eea.net, ref. ə-30111 


\section{INTRODUCTION}

As of 2010, Spain was ranked $42^{\text {nd }}$ in the Global Competiveness Index of the World Economic Forum. ${ }^{1}$ And while competitiveness in Spain was positively affected by the onset of the crisis, between 2005 - when the index was first created - and 2010 Spain slipped 14 places in the global rankings. Moreover, Spain's position is one of the lowest among EU countries, just above Italy - placed $48^{\text {th }}$ and far behind other European countries such as Germany $\left(5^{\text {th }}\right)$, Denmark $\left(9^{\text {th }}\right)$, the United Kingdom $\left(12^{\text {th }}\right)$ and France $\left(15^{\text {th }}\right)$. This is particularly surprising given that the period leading up to the global financial and economic crisis was characterized by relatively robust economic performance.

However, since 2007, the productivity gap between the EU average and Spain started to narrow. Moreover, since early 2010, exports grew at an annual rate of over 15 per cent - driving the recovery - and investment in machinery and equipment started to pick up. True, these trends represent a marked departure from pre-crisis growth patterns. Yet, the positive recent developments will be insufficient for ensuring a successful structural transformation towards a more balanced and competitive economy. The challenge for Spain is thus to properly support these new patterns so they could lay the foundations for a solid recovery and lower unemployment. Evidently, a transformation of this nature will not be easy - it entails restructuring of firms and jobs associated with the previous growth model. Yet, if accompanied by well-designed macroeconomic, labour and social policies, it can lead to the creation of new dynamic firms and quality jobs commensurate with the prevailing skills levels, especially among qualified young graduates.

With this in mind, Section 2 of this paper examines the underlying drivers of deteriorating competitiveness before the crisis: multi-factor productivity, job quality and investment. The paper argues that the economic growth patterns in Spain before the crisis moved the country away from sustainable sources of comparative advantage, which had devastating consequences for labour productivity and, therefore, for competitiveness. ${ }^{2}$ Section 3 looks at recent developments in a

${ }^{1}$ Since 2005, the World Economic Forum bases the construction of its Global Competitiveness Index (GCI) on a highly comprehensive number of indicators (over 100) that capture the microeconomic and macroeconomic foundations of national competitiveness. In the 2010 Report, the Index featured 139 economies (World Economic Forum, 2010).

${ }^{2}$ In general, the deterioration of competitiveness in Spain has been associated with limited productivity gains relative to other European countries. Indeed, there are numerous studies that analyse how labour productivity is related to competitiveness (Harrington, 1991; Porter et al., 1995; and Martínez and Rubiera, 2000 for the Spanish case). In fact, The OECD defines competetiveness as the "ability of companies, industries, regions, nations, and supranational regions to generate, while being and remaining exposed to international competition, relatively high factor income and factor employment levels on a sustainable basis". As such, it is argued that countries' competitiveness is determined in mainly by production costs and, in particular, by the unit labour 
number of these areas with a view to understanding how best to support the ongoing transformation. Section 4 draws policy conclusions from the analysis and the final section concludes.

\section{UNDERLYING CAUSES OF COMPETITIVENESS BEFORE THE CRISIS: MULTI-FACTOR PRODUCTIVITY, JOB QUALITY AND INVESTMENT}

\subsection{The composition of growth was principally due to an increase in labour intensity}

A decomposition of value added growth in Spain shows that growth following 1995 was clearly due to a strong increase in the contribution of labour input at the expense of capital (Figure 1); a reversal from the period 1981-94. In fact, at 64 per cent, the contribution of labour to value added growth in Spain between 1995 and 2007 far outweighed the contribution in other countries. Moreover, during this period, the contribution of capital fell to 53 per cent, compared with 58 per cent between 1981 and $1994 .^{3}$ In comparison, in a select group of countries in the Eurozone ${ }^{4}$ for which information is available, both labour and capital utilization rose during the most recent period of expansion.

As a consequence, the contribution of multi-factor productivity (MFP) ${ }^{5}$ to growth between 1995 and 2007 in Spain was negative (-17 per cent), driven in part by the fact that MFP contribution to growth in the two dominant sectors (construction and, to a lesser degree, manufacturing of non-metallic goods) was negative. This stands in stark contrast to the positive MFP contribution of 19 per cent in the period 1981-94. In comparison, while MFP contributions to growth decelerated in the Eurozone, it remained comparably robust at 19 per cent between 1995 and 2007.

costs - calculated as the ratio of wages to labour productivity (Dornbusch, 1980; Jogerson and Motohashi, 2003).

${ }^{3}$ The same analysis was carried out for the period 1981-1990, i.e. excluding the economic crisis of 1991-1994. This analysis illustrates that the contribution of production factors during this shorter period follow a similar trend than the one observed for the larger period 1981-1994. Indeed, between 1981 and 1990 the contribution of labour input to value added growth was 26.5 per cent, compared to 51.1 per cent for the case of capital input and 22.3 per cent for the case of multifactor productivity.

${ }^{4}$ Eurozone includes countries for which available information on growth accounting exists in the EU KLEMS database. These countries are: Austria, Belgium, Spain, Finland, France, Germany, Italy and the Netherlands.

${ }^{5}$ MFP indicates the efficiency with which inputs are being used in the production process (Timmer et al., 2007). Although not the purpose in this study, it is important to mention that under strict neo-classical assumptions, MFP growth also measures disembodied technological change. 


\section{Figure 1}

Contributions to gross value added growth, by input, 1981-94 and 1995-2007 (percentages)

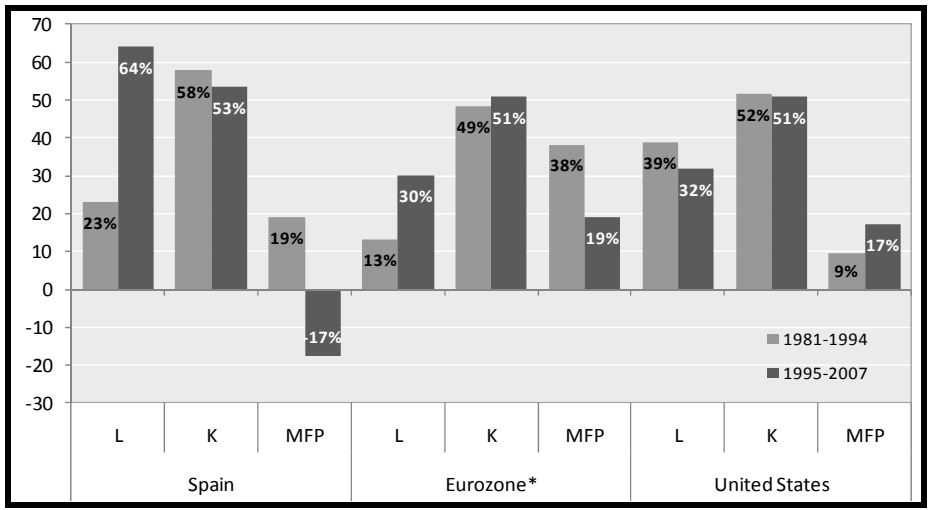

Note: $L$ refers to contribution of Labour input growth; $K$ to contribution of Capital input growth; and MFP to contribution of multi-factor productivity growth.

* Eurozone calculations refer to the weighted average of countries for which available information on growth accounting exists in the EU KLEMS database. These countries are: Austria, Belgium, Finland, France, Germany, Italy and the Netherlands.

Source: EU KLEMS.

\subsection{Growth in labour input was primarily in low-skilled areas}

While the shift towards greater labour utilization was associated with strong employment growth, there was a disproportionate increase in the contribution of hours compared to labour composition, i.e. quality of the labour input or human capital improvements. In fact, over 50 per cent of the increase in value added was due to the increase in the number of hours worked (Figure 2). In contrast, in other countries, such as Ireland - which had a similar employment position over a decade ago - both hours and labour composition contributed positively to overall labour input. In fact, over the period 1995-2007, the employment rate in Ireland increased by 12.4 percentage points, compared to less than 9 percentage points in Spain. ${ }^{6}$

\footnotetext{
${ }^{6}$ In Ireland, a 13 percentage-point increase in the contribution of labour input was accompanied by a 22 percentage-point increase in the contribution of capital input. Moreover, the contribution of hours decreased by 4 percentage points to 28 per cent, despite the 12.4 percentage point increase in the employment rate between 1995 and 2007. The decrease in the contribution of hours was largely outpaced by the increase in labour composition in Ireland.
} 


\section{Figure 2}

Contributions to gross value added growth by factors in the labour input, 1981-94 and 1995-2007

(percentages)

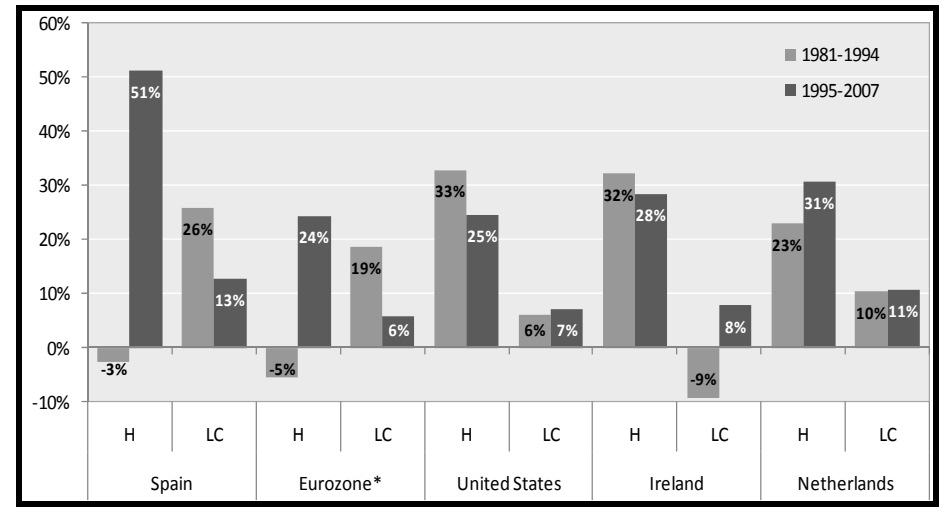

Note: $\mathrm{H}$ refers to the contribution of total hours worked; $L C$ to contribution of labour composition or human capital improvements.

* Eurozone calculations refer to the weighted average of countries for which available information on growth accounting exists in the EU KLEMS database. These countries are: Austria, Belgium, Finland, France, Germany, Italy and the Netherlands.

Source: EU KLEMS.

This decline in the contribution of labour composition to growth has occurred despite the fact that educational attainment in Spain, like in most advanced economies, has increased dramatically over the past two decades (Figure 3). Indeed, among EU-15 countries, the proportion of people who have completed tertiary-level education has increased in all countries - except Germany ${ }^{7}$ - when comparing new entrants (persons aged 25-34) with the previous cohorts. For Spain, 38 per cent of persons aged 25-34 have completed tertiary-level education, which is 5 percentage points higher than the EU-15 average. Moreover, compared with previous cohorts in Spain, notably those aged 45-64, the increase from 21 per cent among this group is particularly dramatic.

\footnotetext{
${ }^{7}$ The stagnation in the improvement of intergeneration educational attainment in Germany is due to a fall in the educational attainment among men (ILO, 2011a).
} 
Figure 3

Percentage of the population that has attained tertiary education in 2009 , by age group (percentages)

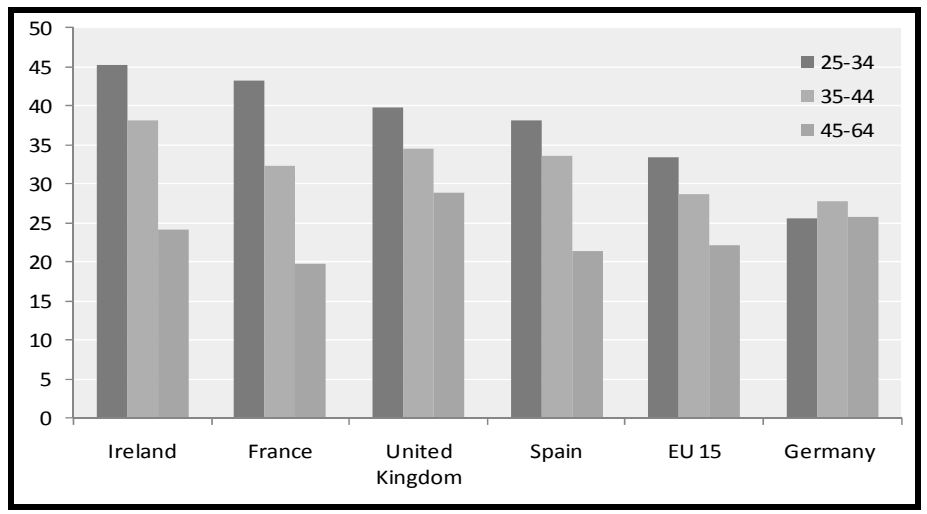

Source: Eurostat database.

In fact, one of the principal reasons behind labour composition's low contribution to value added growth is that the increase in educational attainment was not matched by an increase in the quality of jobs created. The construction sector accounted for over 19 per cent of total employment growth during the precrisis period, rising to more than one-third if employment in real estate activities is included. Consequently, as of 2008, figures for employment by occupation show that 52 per cent of jobs in Spain were concentrated in middle-skilled activities, such as clerks, shop and market sales, craft and related trade jobs; and close to 15 per cent in low-skilled or elementary occupations (Figure 4). ${ }^{8}$ Only roughly 25 per cent of jobs were high-skilled in nature: 13 per cent of jobs were scientific and intellectual professional activities and another 12 per cent technicians and associated professionals. Interestingly, this share of high-skilled occupations in total employment had increased by 7 percentage points compared to 1995, at the expense of a decrease in the share of middle-skilled activities. Meanwhile, the share of low-skilled occupations remained stable between 1995 and 2008.

\footnotetext{
${ }^{8}$ A comparison of similar - but not identical - occupational categories reveals that less than 10 per cent of jobs in the EU-15 were low-skilled or elementary compared to nearly 15 per cent in Spain. Similarly, more than 31 per cent were high-skilled in the EU-15 compared to only 25 per cent in Spain.
} 
Figure 4

Skill composition of employment by occupation* in 2008

(percentages)

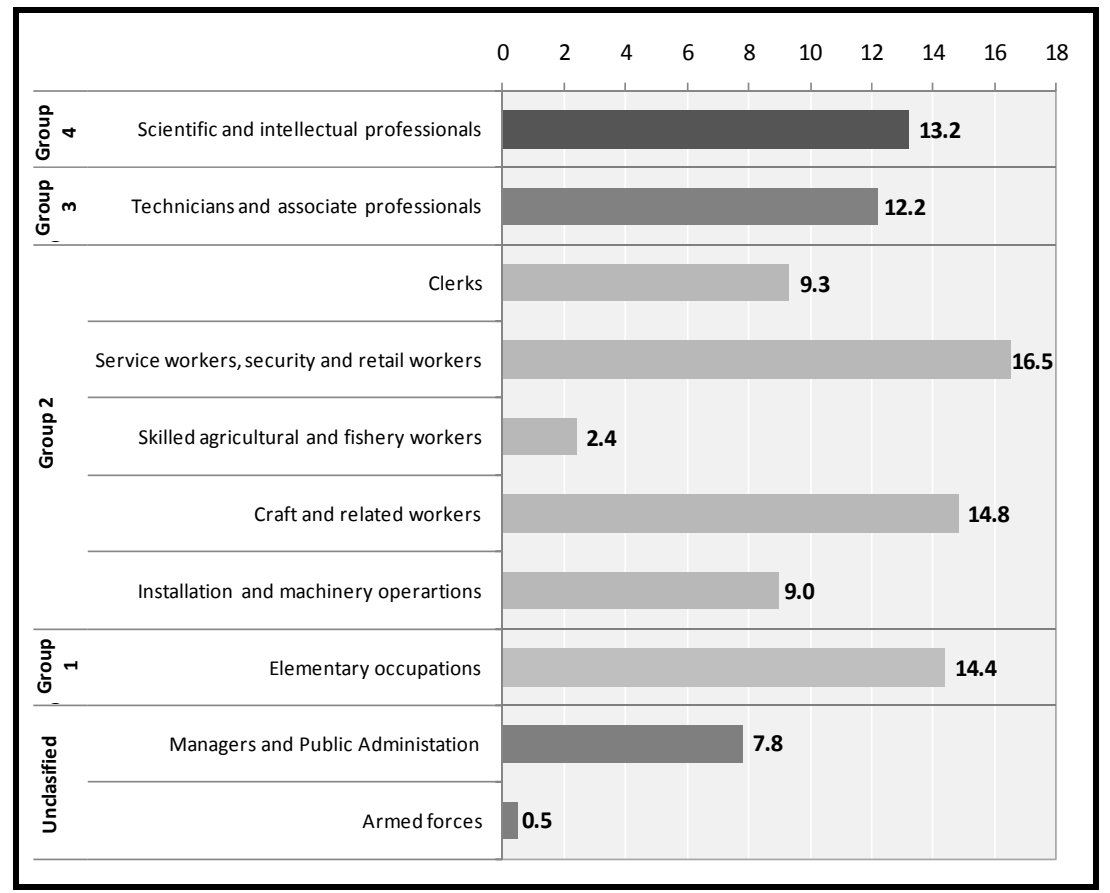

* Group 4 corresponds to the occupations having the highest skill level and Group 1 to those with the lowest skill level. Some occupations remain unclassified because there are significant skill level differences among the jobs classified within each group.

Note: Employment by occupations was taken from national sources and organized in groups by skill composition following the methodology recommended by the International Standard Classification of Occupations (ISCO-88) of the ILO.

Source: IILS estimates based upon national sources.

\subsection{Investment growth was highly concentrated in housing-related activities}

Since 1995, investment in Spain grew quite rapidly, rising by nearly 10 percentage points to reach 31 per cent of GDP at its peak in 2007 (Figure 5). The average annual growth rate in real investment over this period was an impressive 10 per cent. Even with the onset of the crisis, during which investment fell dramatically, at 23 per cent of GDP in 2010, it was still higher than the EU27 average of 18 per cent where investment growth has stagnated since 1995. During the growth period, however, there were important developments with respect to the composition of investment, especially in Spain. 


\section{Figure 5}

Evolution of total investment in real terms and as a percentage of GDP, 1995-2010

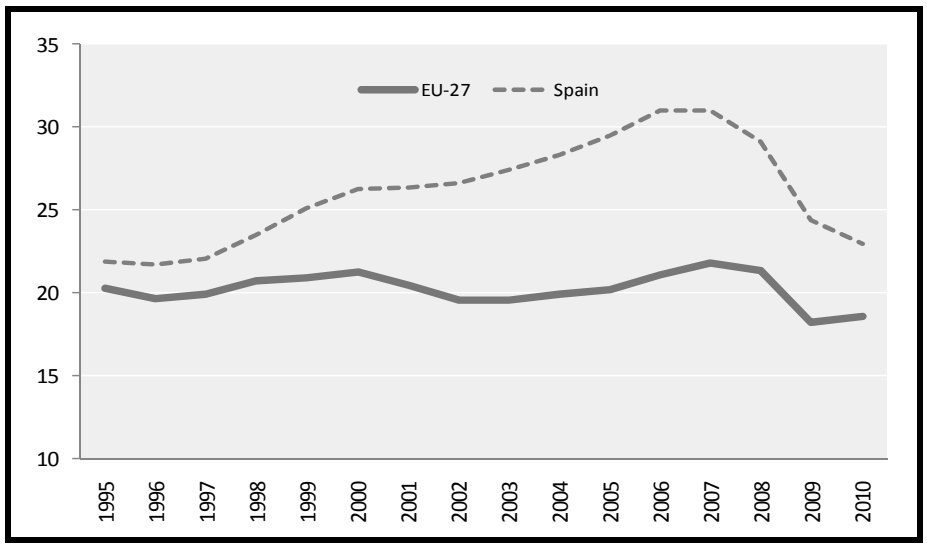

Source: Eurostat and BBVA-Ivie Fundation.

In fact, in terms of the weight of the different asset types in total investment flows, residential investment and non-housing related construction have accountted for the bulk of the growth in investment, i.e. more than two-thirds of total investment growth between 1995 and 2007 (Figure 6). ${ }^{9}$ In particular, residential investment - averaging 12.3 per cent growth per annum - accounted for more than one-third of total investment growth over this period. Investment in metal products and machinery also rose dramatically, reaching nearly one-quarter of all investments in 2007 and accounting for approximately 30 per cent of investment growth.

\subsection{ICT capital investments have lagged}

In comparison, ICT-related investment in Spain has remained low compared to non-ICT investment. ${ }^{10}$ In 2007, for example, ICT-related assets represented 13.5 per cent of total investment (Figure 6). On a positive note, ICT-related investment within the metal products and machinery asset category recorded strong investment growth over the period 1995-2007, i.e. 40 per cent annually, but as of 2007 it constituted less than 10 per cent of total investment.

\footnotetext{
${ }^{9}$ Number of years for which detailed data are available.

${ }^{10}$ ICT investment refers to all investment in information and communication technology (ICT). In accordance with the 1993 System of National Accounts, ICT investment covers information technology equipment, communications equipment and software used in production for more than a year. OECD, 2008; 2004; and 2003.
} 


\section{Figure 6}

Shares of investment by asset type in total investment in 1995 and 2007, and in the change between 1995 and 2007

(percentages)

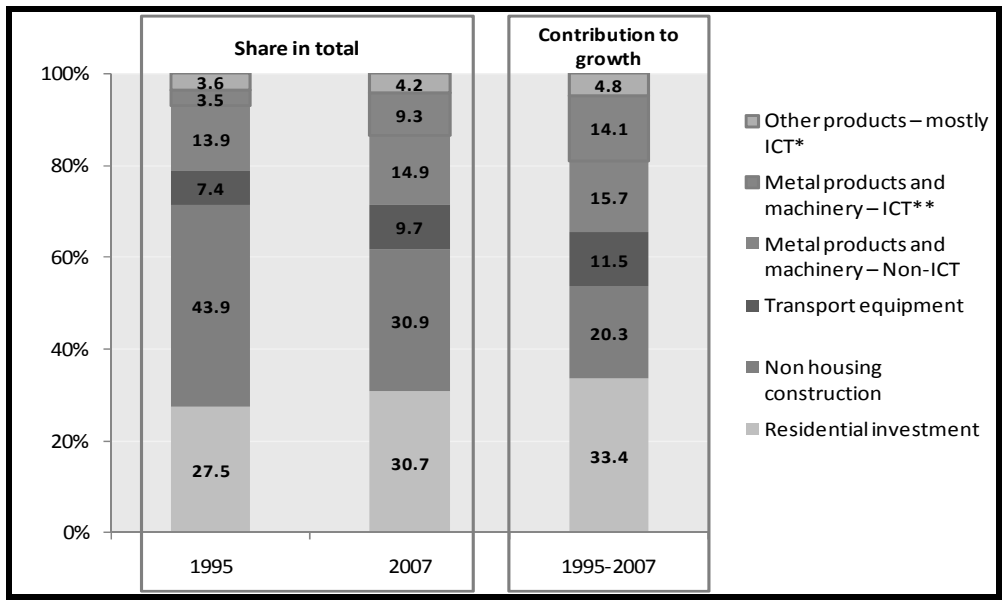

* Around 85 per cent of Other products' investment corresponds to investment in Software and therefore to ICT investment.

** ICT investment in Metal products and machinery corresponds to Hardware and Communications-related assets.

Source: BBVA-Ivie Fundation.

Moreover, between 2000 and 2007, ICT capital accumulation accounted for a little more than 12 per cent of the total capital accumulation. While this is higher than during previous decades (Figure 7), it remains much lower than in other advanced economies, such as the United States (33.5 per cent) and Germany (22.8 per cent). Thus, as a share of gross fixed capital formation, ${ }^{11}$ ICT-related investment in Spain was less than 30 per cent as of 2007. This too is considerably lower than in other advanced economies, such as the United States and the United Kingdom, where the share of ICT assets represented around 50 per cent of gross fixed capital formation.

${ }^{11}$ Gross fixed capital formation (GFCF) measures only the value of net additions to fixed assets, and therefore excludes a number of financial assets, as well as stocks of inventories and other operating costs - which explain why ICT assets have a higher share in GFCF than in total Investment. However, GFCF is the most comparable measurement of investment across countries, which is the purpose of including it in this analysis. 


\section{Figure 7}

Increase in ICT capital stock as a share of growth in real fixed capital stock in Spain, the United States and the United Kingdom, 1980s, 1990s and 2000-07

(percentages)

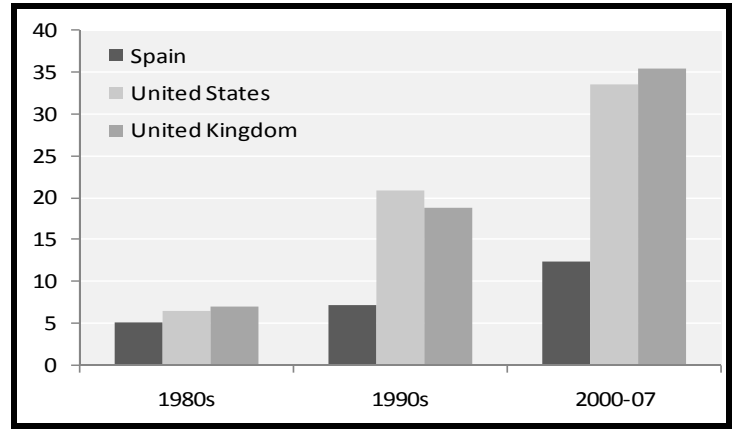

Note: Capital stock corresponds for real fixed capital stock to ensure comparability.

Source: EU KLEMS.

Indeed, over the past decade ICT has been a dynamic area of investment in many advanced economies - owing to rapid technological progress and the steep decrease in prices of ICT goods - and has been an important source of new growth areas. In a select range of advanced economies analysed, including the United States, ICT investment has grown even faster than GDP - increasing its contribution to economic growth. For instance, during the period 1995-2007, contribution of ICT input to gross value added growth attained 17 per cent in the Eurozone and 25 per cent in the United States.

In comparison, ICT contribution to output growth in Spain has trailed considerably. In fact, it contributed only 13 per cent during 1995-2007. These trends partially explain the lacklustre gains in labour productivity given that ICTintensive economic sectors ${ }^{12}$ exhibit, on average, stronger growth in productivity. For example, from 2000 to 2007, ICT-intensive sectors in Spain experienced an annual productivity growth of 2.4 per cent, compared with 1.5 per cent for non-ICT-intensive sectors. As such, ICT-intensive sectors are raising - or at least sustaining - total labour productivity despite their low share in total output during the period. Moreover, the top two sectors for employment creation in Spain between 2000 and 2007, construction and real estate activities,

${ }^{12}$ Industries were classified either as intensive users of ICT or as non-intensive users of ICT, following the definitions by Mas and Quesada (2006). As in their study, two sectors were excluded for this productivity analysis: (i) the agricultural sector, because the very sharp reduction of employment in the sector during the periods analyzed produces an unrealistic extremely fast productivity growth that bias the overall calculation; (ii) the public sector, mainly because it is difficult to interpret properly labour productivity improvements in the public sector. 
exhibited weak and negative annual labour productivity growth, i.e. 0.6 per cent and -2.7 per cent, respectively. Therefore, even at a small scale, ICT investment has proven to be an important contributor to labour productivity growth in Spain.

\subsection{Nominal unit labour costs rose dramatically in relation to productivity}

The strong growth period starting in the early 1990s led to a comparably high level of inflation of consumer and producer prices during the period preceding the crisis. Between 2000 and 2007, producer prices in Spain had increased at an average annual growth rate of 4 per cent, compared to 2.2 per cent for the Eurozone average.

Similarly, the increase in nominal labour costs in Spain was well above that observed in other European countries. ${ }^{13}$ Between 2000 and 2007, nominal labour costs in Spain increased by an average 4.4 per cent annually compared to 2.9 per cent in the Eurozone and 1.7 per cent in Germany. However, the comparably strong levels of producer price inflation in Spain adversely affected total labour cost developments vis-à-vis its European counterparts. In fact, once producer price inflation is taken into account, real product wages barely grew during the period of expansion. In fact, real product wages grew at an average annual pace of 0.1 per cent between 2000 and 2007 - which is significantly below the gains ( 0.6 per cent per annum) in the Eurozone area and well below productivity gains in Spain.

Moreover, the increases in nominal labour costs in Spain were not due to factors related to wages and salaries. These increases were principally driven by non-wage related costs, which rose at an average rate of 2.2 per cent per annum in real terms compared with 1 per cent on average for wages and salaries. Relative to other European countries, the difference is significant. Indeed, real nonwage labour costs in the Eurozone grew by only 0.2 per cent on average and in the EU-27 by 0.8 per cent on average, and in both cases real non-wage costs grew at a slower rate than real wages and salaries. In Spain, the non-wage costs increases were due primarily to steep increases in contributions related to the social security system, such as illness, maternity, work accident and invalidity benefits. These mandatory contingency contributions did not increase much more than other items - around 4 per cent per annum in average - but given their relative importance in total non-wage costs, i.e. around 60 per cent at the end of 2007, they contributed to more than half of the increase. Redundancy costs were another important driver of non-wage costs during this period, recording an

13 Labour costs are composed of (i) wages and salaries and (ii) mandatory contributions and other non-wage labour costs (i.e. non-wage labour costs). 
impressive annual growth of around 10 per cent on average, with their share in total non-wage costs rising to almost 15 per cent. ${ }^{14}$

\section{RECENT DEVELOPMENTS TOWARDS IMPROVED COMPETITIVENESS}

As seen in the previous section Spanish competitiveness suffered from a sharp decline during the economic boom that preceded the crisis driven fundamentally by a deterioration in labour productivity. Since 2007, however, labour productivity has improved in Spain giving rise to a raise in competitiveness. This section illustrates the factors behind this growth in productivity since the onset of the crisis.

\subsection{Productivity and competitiveness have improved of late}

Since 2007, the productivity gap between the EU and Spain has started to narrow (Figure 8, panel A). The process began moderately in 2007, with labour productivity growth in Spain outpacing its major European counterparts by more than 0.7 percentage points. By 2009, annual labour productivity among EU-14 countries fell on average by 1.7 per cent whereas in Spain the gains were close to 3 per cent. Even in 2010, the gap continued to narrow. This narrowing of the productivity gap between Spain and its European counterparts is principally a function of changes in employment patterns. Employment fell much more steeply in Spain relative to output when compared with other European countries (the employment rate in Spain decreased by 6.5 percentage points between the first quarters of 2007 and 2011) driving productivity upwards; whereas in the EU-14, efforts to maintain workers tied to their jobs drove labour productivity downwards.

A reversal in the upward trend of price and cost indicators is another welcome development (Figure 8, panel B). In the course of 2009, core inflation in Spain fell to levels close to the EU-15 average, reflecting the drop in domestic demand. In addition, unit labour costs in Spain decreased much faster than in the

${ }^{14}$ Although not analysed in the body of this paper, it is important to mention that the collective bargaining mechanism in place also played a role in the determination of labour costs in Spain. Indeed the results of the econometrical analysis presented in Annex A, estimated to shed light on the various determinants of wage and non-wage costs in Spain, show that union coverage growth rates (a proxy for the extent of collective bargaining in the country) have a positive impact on wage and nonwage cost growth rates. The reason is that the expected rate of inflation is the most important reference for wage indexation in multi-year agreements between unions and employers' organizations in Spain. Although similar practices are evident in other countries, a key feature of the Spanish system is the "pay review clause" which allows correction in wages when actual inflation exceeds expected inflation (but not the opposite) (ILO, 2011b; Malo, 2011). 
rest of Europe - a decline of 2.5 per cent between the fourth quarter 2008 and 2010, compared with 0.6 per cent in the EU-15. The decrease in inflation had a key role in the decline of unit labour costs in Spain relative to its European counterparts. However, the difference between Spain's and EU-15 countries' productivity patterns was also influential in this regard. Since 2008, the strong decline in labour productivity in the EU-15 was almost offset by the increase in wages, which smoothed the decline in unit labour costs. In Spain, however, a slight increase in wages was largely outpaced by the strong increase in productivity and this accelerated the downward trend in unit labour costs.

Figure 8

Recent trends in price, cost and productivity indicators since the onset of the crisis, 2007-10

Panel A: Change in labour productivity in EU$14^{*}$ and Spain, 2007-10 (percentages)

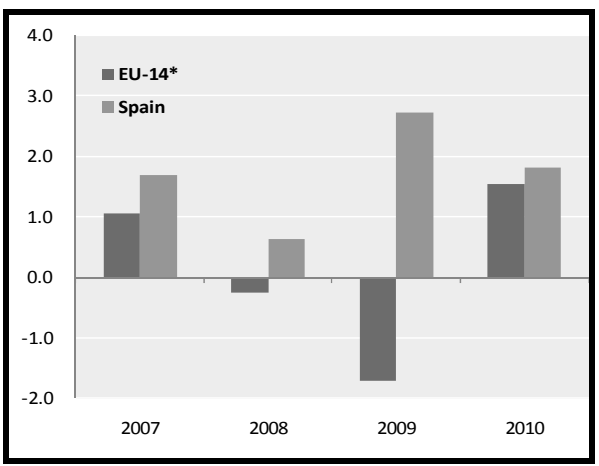

${ }^{*}$ Weighted average for the EU-15 without Spain.

Source: The Conference Board Total Economy Database.
Panel B: Evolution of $\mathrm{HCPI}^{*}$ and unit labour costs** in EU-15 and Spain, Q1 2007-Q1 2011 (Q1 2007=100)

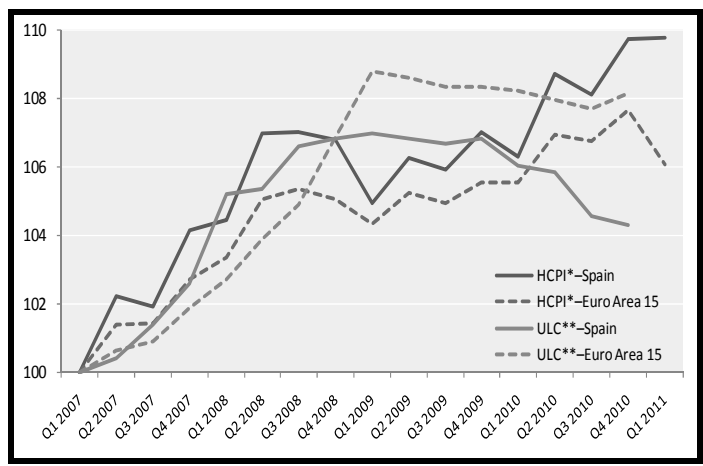

${ }^{*}$ Harmonized consumer price index; ${ }^{* *}$ Nominal unit labour cost Source: Eurostat database.

As a result, the gap between Spain and the rest of Europe (previously 4 to 1 ) in terms of the increases in the cost of labour and in labour productivity has reversed. And while the reversal or the trends since 2008 is principally a function of changes in employment patterns, these developments represent an opportunity for Spain to seize the relative gains in an effort to improve overall competitiveness in a sustainable manner. Between the end of 2008 and 2010, with the declines in price and cost indicators relative to the EU-27 and OECD averages, foreign competitiveness had already improved by close to 3.5 per cent. ${ }^{15}$

\footnotetext{
${ }^{15}$ Calculations for September 2008 to September 2010, which is the latest available information for external competitiveness (trends calculated based on export price indexes rather than CPI).
} 


\subsection{Growth in exports and moderate changes in composition}

These changes in productivity and competitiveness patterns are already leading to a new pattern of growth in Spain. Indeed, following an unprecedented fall of nearly 20 per cent between the third quarter of 2007 and the third quarter of 2009 , the growth rate of exports started to pick up from the beginning of 2010 . By February 2011, exports had grown close to 15.5 per cent compared with the same period the year before - 22.5 per cent in nominal terms - and were already 3 per cent above the peak level attained before the crisis. As such, external demand during 2010 was the main - indeed only - engine of economic growth (domestic demand continued to decline). This trend is expected to continue and exports are expected to drive economic growth in 2011. ${ }^{16}$

Moreover, during the last year, there have been signs of a possible shift in the composition of exports. Indeed, industrialized products have regained their strength and have grown faster and contributed more to total growth of exports than the durable goods sector (Figure 9). ${ }^{17}$ The automobile sector was the fastest growing sector during the past year, growing by over $€ 500$ million (18.3 per cent) between February 2010 and February 2011. Exports of mineral fuels, oils and distillation products more than doubled over this period. Together, these two sectors accounted for roughly one-third of the overall increase in exports. Semimanufactured products from iron and steel and the machinery and mechanical appliances sector also showed strong improvements, accounting for close to onefifth of the gains in exports.

Moreover, a number of these industrialized products showed an important increase in comparative advantage relative to other Spanish products between January 2010 and January 2011. Noteworthy in this regard is the gain in comparative advantage of complete industrial plant sector, which includes industrialization of chemical, iron, steel and timber products, machinery construction and mineral extraction. These sectors gained 10 points in comparative advantage but accounted for a relatively small portion (less than 1 per cent) of the growth in exports over this period (Figure 10, panel A). Other sectors, accounting for a larger portion of the export gains, have also shown gains in comparative advantage. For instance, the ships, boats and floating structures sector - which accounted for 6 per cent of total export growth since the beginning of 2010 - gained close to 7 points in comparative advantage. The automobile sector showed an increase in comparative advantage too, as well as the sector comprising the production of articles of iron and steel and the pharmaceutical sector.

\footnotetext{
${ }^{16}$ Banco de España, 2011.

${ }^{17}$ Especially taking into account that Spanish manufacturing exports were characterised by their low level of sophistication during the period of boom economic growth (Minondo, 2007).
} 
Figure 9

Top five growing export sectors, February 2010-February 2011

(millions of Euros and percentages*)

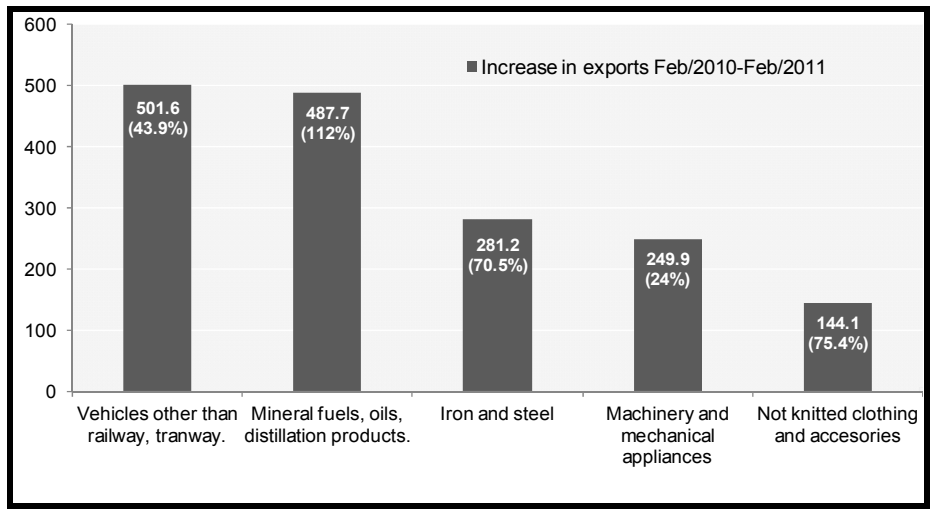

${ }^{*}$ Figures in parenthesis show percentage changes.

Note: Export information comes from TARIC classification.

Source: IILS estimates based upon National sources.

In a number of instances the gains in comparative advantage have been a cyclical reversal of previous declines that occurred as a result of the onset of the crisis (e.g. iron and steel articles, zinc and articles thereof, ceramic products, articles of stone, cement, etc. and the automobile sector). More interestingly, though, are the sectors that exhibited their first upturn in comparative advantage, at least since 1996 (when information of this nature first became available). For example, the wadding, felt and nonwovens sector started to show a strong positive comparative advantage in late 2009 (Figure 10, panel B) and by January 2011 was ranked seventh highest for internal competitiveness among export sectors. Likewise, the metal tools and implements sector and the pharmaceutical export industry started to gain comparative advantage only in recent years and made noteworthy gains in 2010. These trends reinforce the hypothesis that a sustainable change is taking place in the composition of exports. 
Figure 10

Increase in comparative advantage during the period January 2010-January 2011

Panel A: Top ten products in terms of their increase in comparative advantage during Jan-2010-Jan$2011^{*}$

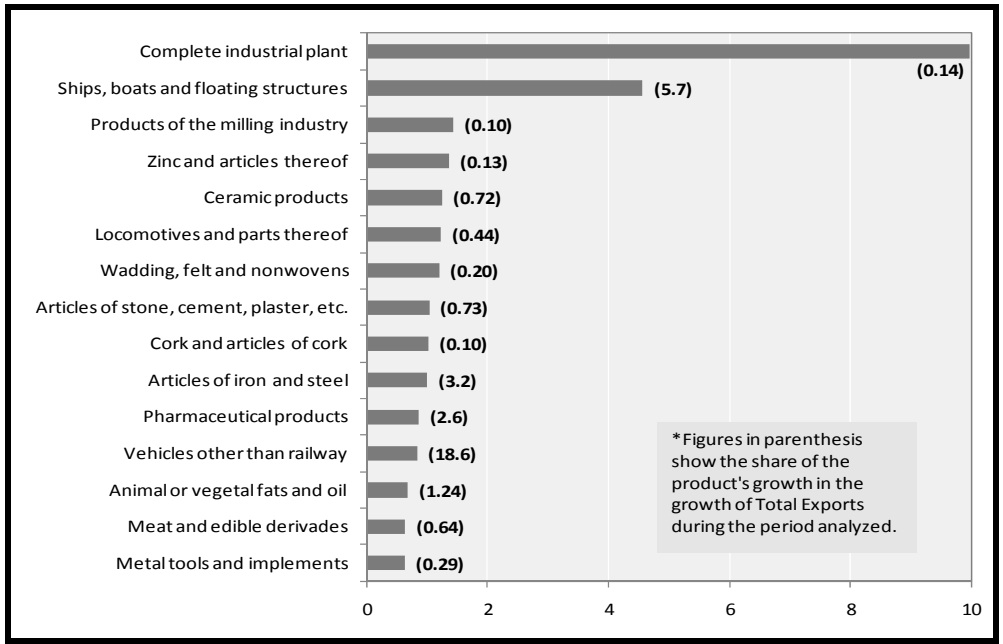

Panel B: Sectors showing a first time increase in comparative advantage (Dodges and Riedel Measure)

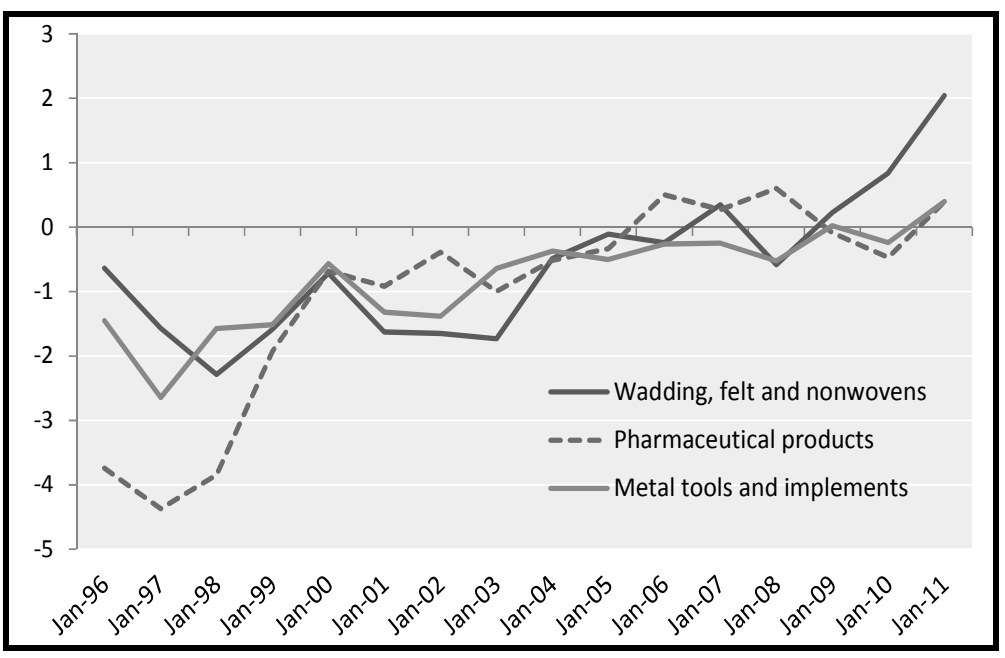

Note: Calculations are based on the Donges and Riedel Measure (Donges and Riedel, 1977) $(D R M=[(X i j-M i j) /(X i j+M i j)] /[(\Sigma X i j-\Sigma M i j) /(\Sigma X i j+\Sigma M i j)]$ and Wolter Index (Wolter, 1977) $(W I=(X i j / M i j) /(\Sigma X i j / \Sigma M i j)$. These indicators provide information about the relative export performance of a certain industry or product with respect to other industry groups of the same country. The two different methodologies applied coincided in the results, giving confidence to the analysis provided.

Source: IILS estimates based on the Taric Database of the Spanish Ministry of Industry, Tourism and Trade. 


\subsection{Investment, however, has not yet shown signs of a sustained recovery}

Investment suffered deeply from the 2008 crisis and has yet to bottom out. In fact, it has been falling continuously since the beginning of the crisis - at an average annual rate of -2.5 per cent - and by the fourth quarter of 2010 real investment had fallen by close to 28 per cent since the beginning of 2008 .

Residential investment has exhibited the steepest fall since 2008 - by 4 per cent - followed by transport equipment and metal products and machinery - by 3.3 and 2.1 per cent, respectively (Figure 11). The reduction in residential investment is the main driver of the overall fall, constituting nearly 40 per cent of the total decline. The other 60 per cent is comparatively equally distributed between the other four non-residential business investment sectors - though a little less for transport equipment. By the end of 2010, the situation had altered only slightly and signs of a potential recovery were yet to be seen. Only the metal products and machinery sector had shown minor investment growth -0.15 per cent. The Bank of Spain estimates that investment in capital goods and other products will start to recover in 2011, although the pace of growth is expected to be relatively modest compared with the recoveries experienced following past crises. $^{18}$

Figure 11

Fall in investment by asset type between Q4 2008 and Q4 2010, and contribution to the decrease of total investment

(percentages)

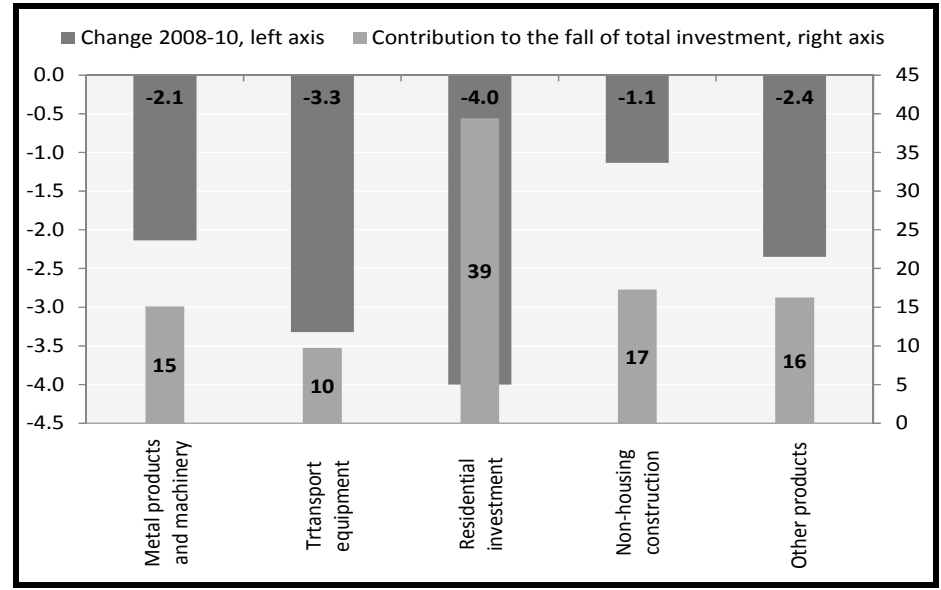

Source: Eurostat database.

${ }^{18}$ Banco de España, 2011. 


\section{POLICY CONSIDERATIONS}

Despite the unprecedented economic growth in Spain over the past decade, overall competitiveness has declined sharply and remains low in comparison to other advanced economies - highlighted in particular by a deterioration in labour productivity. As seen in the previous section, there are some encouraging signs with respect to a recent narrowing of the productivity gap, improvements in overall competitiveness and a welcome shift in the contribution of exports to growth - and in their composition. However, investment rates remain - at least for the moment - lacklustre. Therefore, moving forward, to promote and encourage quality employment gains and encourage more balanced growth and investment developments, efforts will be needed to address these shortcomings and build upon some of the successes achieved of late.

\subsection{Encourage innovative capacity to increase productivity}

There have been some encouraging signs with respect to productivity gains in ICT-related sectors. In fact, the already highly productive ICT-related sectors in Spain experienced strong gains since 1995, but these continue to account for only a small share of the overall investment compared with their counterparts. Reform efforts could focus on encouraging further gains both in this area and in other innovative sectors of the economy.

- Measures to foster ICT investment could help to increase the innovative capacity and increase productivity. The Government has made some efforts in this direction already, but only on a temporary basis - e.g. the asset redemption leeway for corporate tax payers. ${ }^{19}$ However, promoting investment in high value-added sectors will require conditional investment initiatives that are more permanent and more targeted to specific sectors. Efforts of this nature have been carried out by other countries with successful results. For example, during the 1980s to the early 1990s the Republic of Korea introduced greater research and development expenditures, with a special focus on new technologies such as semiconductors, new materials development, super minicomputers and biotechnology. ${ }^{20}$ Rapid technolo-

${ }^{19}$ The asset redemption leeway for corporate tax payers was put in force as part as the efforts to support firms. This new law stipulated that corporate tax payers willing to invest in new assets will be allowed to pay them back at will, provided the assets were acquired during a chargeable period between 2009 and 2010 and the company retains staff.

${ }^{20}$ In 1992, the Government of the Republic of Korea pledged over 121 billion won for the "G-7 project" high technology project alone. Furthermore, the Law for the Promotion of Industrial Technology Development was put forth, which required large companies to create research centres and small or medium companies to form research consortia. Private corporations were responsive to these government incentives and they quadrupled operations in research and development throughout the 1980s. Concurrently, the Government administered foreign invest- 
gical progress in the ICT producing industry (especially manufacturing) contributed to rapid productivity growth in the Republic of Korea - of 1 percentage point between 1996 and 2001, which was the highest among OECD countries during that time. ${ }^{21}$ However, the ICT-related sector is just one example of how to improve the overall investment climate and to orient incentives towards higher value-added sectors.

- Technological transfer could also be enhanced by moving ahead quickly with the proposal to allow researchers to create innovative firms. Although the present legislation gives incentives for university researchers and professors to work in technology-based companies (promoted and owned by the university), the law has yet to be implemented. The Law on Sustainable Economy is a window of opportunity for unlocking this potential.

\subsection{Leverage further gains in the export sector while being mindful of environmental concerns}

The continued diversification of the existing growth model will be a key component of the adjustment process. There are already some early indications of this transformation via recent developments in external demand, but there is considerable potential to leverage further these gains: the share of exports to GDP in Spain was 26 per cent in 2008, which is low in comparison with the EU-15 average of close to 40 per cent. Moreover, the share of high value-added export products in total exports, at 48 per cent in 2010, is considerably lower in Spain than in some of its European counterparts, such as Germany (72 per cent) and Italy (68 per cent). As such, further gains could be achieved by continuing to diversify the export sector, both in terms of composition and destination.

- Industrialized exports products - e.g. mineral fuels and distillation products; vehicles other than railway, tramway; energy products; chemicals, iron, and other metals, etc. - have regained their strength and are growing faster and contributing more to total growth of exports than the durable goods sector. Moreover, in a number of instances there have been strong gains in the comparative advantage of a number of emerging sectors, e.g. the metal tools and implements sector and the pharmaceutical export industry started to gain relative export advantage only in recent years. Encouraging the development of sectors that are more intensive in the use of technology would be an important step towards the sustainable deve-

ment and technologies through redesigned incentive systems, which proved particularly instrumental for the electronics industry. Lastly, to help fuel this growth, the Government invested 1,238 billion won in 1980 and then 5,158 billion in 1990 in technology and science education, increasing the total budget for these activities by 17.1 per cent and 19.6 per cent, respectively (Ho and Shin, 1997; Smith, 1997).

${ }^{21}$ Federal Statistical Office. 
lopment of the export sector. For example, governmental measures aimed at promoting the internationalization of firms ${ }^{22}$ could be better tailored towards promoting a better diversification of goods and services.

- Expanding the export base for Spanish goods and services could also open new markets. During the past decade non-EU destinations have increased, but only moderately - from 28 to 30 per cent. Moreover, the top three export partners (France, Germany and Portugal) still accounted for 40 per cent of total exports in 2009. Diversifying its foreign trade relationships, especially with emerging and developing countries, could open up new opportunities. This is particularly the case given that growth in developing countries is expected to be more than double that of advanced economies during the next two years -6.5 per cent in the former compared to 2.5 per cent in the latter. ${ }^{23}$ Moreover, a large part of the growth in developing and advanced countries will be driven by a growing internal demand, which represent an important opportunity for Spanish exporters.

Moreover, experience from other countries shows that putting the right policies in place is central to a successful strategy of boosting economic growth through export promotion. Notable examples of these include the newly industrialized economies in Asia - starting first in Hong Kong (China), Republic of Korea, Singapore and Taiwan, and later in Malaysia, Thailand and Indonesia. ${ }^{24}$ Despite the difference in their national experiences, it is possible to find common elements of policies aimed at promoting exports. The most important being: (i) adequate price incentives through competitive real exchange rate and low levels of anti-export bias arising from import protection; (ii) sound physical infrastructure (e.g. ports, roads, power supplies) and social infrastructure (e.g. well-educated labour force); and (iii) access to credit for exporters, either for investment or export trade financing at favourable interest rates.

A move towards a new economic model, however, should take into consideration environmental changes. Some of the major Spanish sectors are relatively low carbon intensive (e.g. the automobile industry and the electric and electronic equipment sector). Moreover, with the construction sector losing ground as an economic driver and exports gaining pace, Spain has an opportunity for "greening" its growth drivers. However, a number of the industries that have arisen during the last two years are either highly-carbon intensive (e.g. cork and derivatives), highly polluting (e.g. pharmaceutical industry) or highly-energy in-

\footnotetext{
${ }^{22}$ See Chapter 2 of ILO (2011b) for more information.

${ }^{23}$ IMF, 2011.

${ }^{24}$ The proportion of world exports of manufactured goods by the four Asian Tigers (i.e. Hong Kong (China), Republic of Korea, Singapore and Taiwan) increased from 1.5 per cent in 1965 to 5.3 per cent in 1980 and to 7.9 per cent in 1990 . This contributed to an impressive growth in GDP of 14.1 per cent annually on average in the period 1980-90 (Weiss, 2005; IMF, 2011).
} 
tensive (e.g. those manufacturing zinc, iron and steel, cement and plaster, and ceramic products).

Policies must therefore balance the need for growth with the need to reduce greenhouse gas emissions. This can be achieved by promoting $\mathrm{CO}^{2}$ reduction within firms or sectors that experience strong growth. Alternately, supporting lowcarbon industries that have the potential to be productive and innovative, e.g. the electrical and optical equipment industry has the potential to achieve both objectives.

\subsection{Effective wage determination ${ }^{25}$}

A number of factors have been influencing the growth of labour costs in Spain; yet, some were more decisive than others in affecting the variation. To analyse this in more detail, an econometric analysis has been undertaken to shed light on the various determinants of wage and non-wage costs in Spain and their relative importance. ${ }^{26}$

The model pinpoints inflation as the principal factor explaining changes both in wages and in non-wage costs during the period 1996-2008. In fact, the model illustrates that over this period around 30 per cent of the growth in wages, and more than 21 per cent of the non-wage cost changes were due to rising consumer prices.

Based on these relationships, two alternative scenarios have been simulated to illustrate the effects that different inflation and wage policies could have on the growth of labour costs in the future (Figure 12). A number of interesting results arise from the analysis. ${ }^{27}$

- The first finding is that efforts to reduce inflation - scenario 1 - are the most effective measure in reducing nominal labour costs. According to the analysis, efforts to reduce the average annual inflation from 3 per cent to the target 2 per cent of the European Union in four years would reduce the growth rate of labour costs by an annual 1.1 percentage point - through a decrease in the growth rate of wages and non-wage costs of 1.2 and 0.8 percentage points per year, respectively. ${ }^{28}$

\footnotetext{
${ }^{25}$ This section was prepared in collaboration with Paola Ballon during her visit at the International Institute for Labour Studies.

${ }^{26}$ See Annex for an explanation about how the model was constructed and the results of the exercise.

${ }^{27}$ For this the simulation has assumed a 0.25 per cent decrease per year to attain an inflation of 2 per cent in 2014.

${ }^{28}$ Annual growth rates of nominal wages and nominal non-wage costs during the period 2000-07 equaled 4.1 and 5.5 per cent, respectively.
} 
- Moreover, the above is more effective that an imposed decrease in wages, which would adversely affect the well-being of the population and on the recovery of internal demand (already prior to the crisis real wage growth was weak). Indeed, the analysis shows that a decrease in the growth rate of wages - scenario 2 - of 1 percentage point - i.e. from an annual 4.2 to 3.2 per cent in nominal terms - would decrease the growth rate of labour costs by 0.6 percentage points.

Figure 12

Total labour costs simulations (Q1 2010=100)

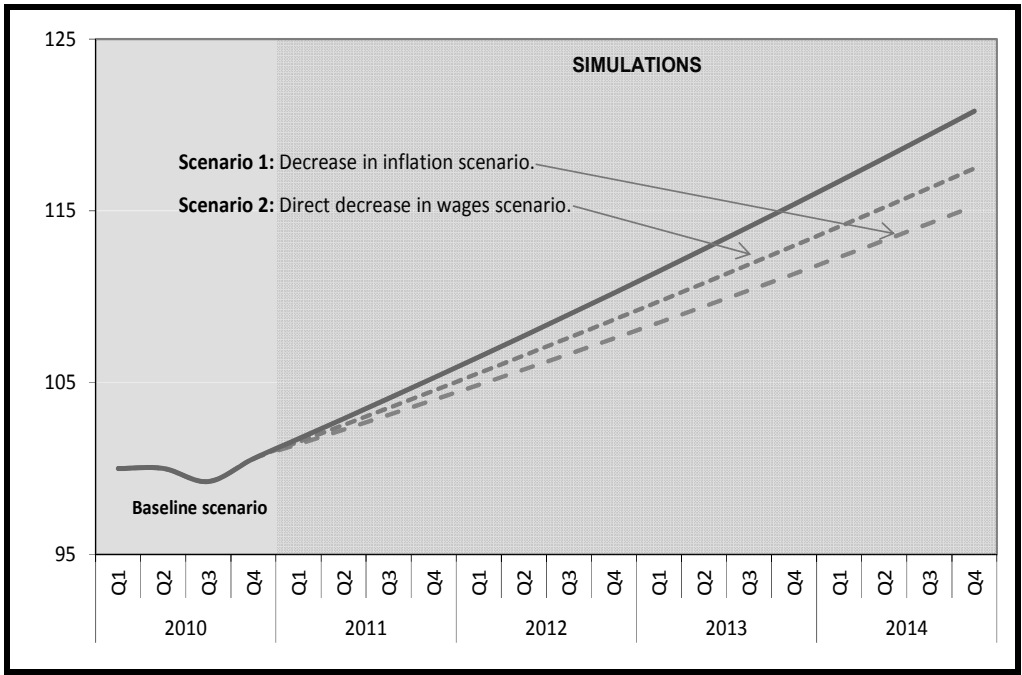

Source: IILS estimates on Eurostat database and national sources.

\subsection{Aligning education, labour market and social policies to the new growth model}

Finally, it is important to consider that a successful change in the growth and investment model, although necessary, will not foster employment recovery automatically. Changing the allocation of resources is often a lengthy process and one which may delay job creation. While market forces are driving change, policy initiatives - along the lines of those described above - can encourage and accelerate this process. In the more immediate term, to complement this, proper labour market reforms will become all the more pressing if Spain is to speed up employment recovery significantly. In fact, empirical evidence shows that labour market reforms might support the transition to a new growth model by sig- 
nificantly speeding up the reduction of unemployment, while fostering productivity and real wage growth. ${ }^{29}$

\section{CONCLUSIONS}

Despite the unprecedented economic growth in Spain over the past decade, overall competitiveness has declined sharply and remains low in comparison to other advanced economies. This is highlighted in particular by a deterioration in labour productivity, which is due to a number of factors, notably: (i) the composition of growth was principally due to an increase in labour intensity (at the expense of capital deepening); (ii) growth in labour input was primarily in lowskilled areas, which is mainly explained by the low-skilled nature of the sectors that accounted for the bulk of growth - principally housing-related; (iii) investment growth leading up to the crisis was principally in low-productivity areas; and (iv) nominal unit labour costs rose dramatically in relation to productivity, widening the gap between Spain and the rest of Europe and further eroding competitiveness.

Underlying the overall weak aggregate picture, there are however, a number of positive developments, which, if properly supported, could lay the foundations for a solid recovery and lower unemployment. Indeed, since early 2010, exports have grown at an annual rate of over 15 per cent, driving the recovery. Already at the beginning of 2011, exports were 3 per cent above their pre-crisis levels, with exports of relatively high value-added products - e.g. chemicals, pharmaceuticals, metals and machinery - exhibiting particular dynamism. External competitiveness has also improved somewhat. More generally, counter to prevailing wisdom, wage levels do not seem to be a constraint on the shift to a new growth model in Spain. Nor were wages at the root of declining competitiveness. These patterns represent a marked departure from pre-crisis growth, which was driven by low-skill-intensive output and debt-led domestic demand notably housing investment.

However, investment rates remain - at least for the moment - lacklustre. Therefore, moving forward, to promote and encourage quality employment gains and encourage more balanced growth and investment developments, it is crucial to complement these recent measures with further efforts to support structural transformation.

${ }^{29}$ The analysis suggests that an all-embracing labour market reform $(5$ per cent reduction in the Nash parameter; 5 per cent reduction in separation rate; 5 per cent increase in matching efficiency; 10 per cent reduction in the cost of vacancies; and 1 per cent increase in search intensity) could reduce the number of years needed to cut the unemployment rate by 10 percentage points by one-third (a reduction of 6.5 years compared with the baseline). See Andrés et al. (2009) for a full analysis. 
This paper shows that, first of all, there is an urgent need to strengthen the Spanish export base - both by encouraging further the development of sectors that are more intensive in the use of technology and by diversifying foreign trade relationships, especially with emerging and developing countries. Measures targeting incentives to foster improved innovative capacity and increased productivity are also welcome steps in Spain.

Moreover, it is important to bear in mind that it is price increases - rather than real wages - that drove nominal wage growth, eroding competitiveness. The key to improving competitiveness therefore lies not in wage cuts - which would perpetuate the unbalanced growth patterns - but in improving the quality of employment and investment through a more comprehensive strategy of aligning economic and labour market policies. As such, Eurozone coordination on wage policies is also crucial to avoid a "race to the bottom".

Although not analysed in this paper, further improvements in product market regulation, especially as regards dynamism of firms, would be a necessary complement for policies aimed to strengthen the Spanish export base and for measures targeting incentives to foster improved innovative capacity. Despite the improvements achieved in product market regulation since $1998,{ }^{30}$ further reforms are needed if Spain is to attain similar OECD and EU-15 levels in a number of areas. For instance, price increases in tradable goods (manufacturing producer prices) in Spain outpaced those in the rest of Europe by a factor of more than two. In this regard, Spain could improve the independence of sector regulators $^{31}$ and reduce legal and administrative barriers to enter certain professional services. ${ }^{32}$ Furthermore, efforts are needed to re-establish dynamism within firms and to create an environment of enterprise creation and development so that entrepreneurs can take advantage of new productive opportunities and are encouraged to expand and grow. As such, Spain needs: (i) to guarantee the financial sector serves the needs of the real economy, to ensure that firms are able to access financing and take advantage of new growth opportunities; and (ii) to re-

${ }^{30}$ See ILO (2011b), for a succinct but complete list of the reforms undertaken in Spain since 1998 to promote competition in the product market.

${ }^{31}$ State control remains high in a number of areas. In particular, independence in sector regulators could be improved: Spain ranks 19 out of 29 in the use of command and control regulation indicators. In some sectors, e.g. airports and water distribution sector regulators have not yet been designated and in others such as the energy sector, the Government has the power to revoke decisions taken by the sector regulator (OECD, 2010).

32 In Spain, the barriers faced by qualified people wishing to enter certain high-value service professions, such as accounting, architecture, engineering and legal services, remain onerous. Recent reforms by the Spanish Government to reduce legal and administrative entry regulations for certain professional services are a welcome step forward. For example, some restrictions on the joint exercise of certain professions as well as on advertising and prices set by professions are being eliminated. 
duce administrative burdens and barriers to business start-up. The effectiveness of this type of reforms and their impact to labour productivity would be an interesting subject for future research.

\section{REFERENCES}

ANDRÉS, J.; BOSCÁ, J.E.; DOMÉNECH, R. and FERRI, J. (2009): Job creation in Spain: productivity growth, labour market reforms or both?. Working Papers No. 0903, International Economics Institute, University of Valencia.

BANCO DE ESPAÑA (2011): Spanish Economic Projections Report. Economic Bulletin, April 2011, Madrid.

BLANCHARD, O. J. and KATZ, L. (1999): Wage Dynamics: Reconciling Theory and Evidence. Working Paper No. 6924, National Bureau of Economic Research, Cambridge.

CARNOT, N.; KOEN, V. and TISSOT, B. (2005): Economic forecasting. New York: Palgrave Macmillan.

DONGES, J.B. and RIEDEL, J.C. (1977): "The expansion of manufactured exports in developing countries: an empirical assessment of supply and demand issues". Weltwirtschaftliches Archiv, 113 (1), pp. 58-87

DORNBUSCH, R. (1980): Open Economy Macro-Economics. New York: Basic Books Inc.

HARRINGTON, H. J. (1991): Business process improvement: the breakthrough strategy for total quality, productivity and competitiveness. New York: McGraw-Hill.

HO, A; SHIN, R. (1997): "The role of science and technology in creating Korea's electronics industry", Asian Affairs, 23 (4), pp. 235-251

INTERNATIONAL LABOUR ORGANIZATION (ILO) (2011a): Germany: A jobcentred approach, Studies on Growth with Equity. Geneva: International Institute for Labour Studies (IILS).

INTERNATIONAL LABOUR ORGANIZATION (ILO) (2011b): Spain: Quality jobs for a new economy, Studies on Growth with Equity. Geneva: International Institute for Labour Studies (IILS).

INTERNATIONAL MONETARY FUND (IMF) (2011): World Economic Outlook: Tensions from the Two-Speed Recovery: Unemployment, Commodities, and Capital Flows. Washington, DC.

JOGERSON, D. and MOTOHASHI, K. (2003): Economic Growth of Japan and the United States in the Information Age. RIETI Discussion Paper Series 03E-015, Research Institute of Economy, Trade and Industry, Tokyo, Japan. 
MALO, M. (2011): Study on the labour market policies in Spain under the current crisis. Discussion Paper No. 210, International Institute for Labour Studies (IILS), Geneva.

MARTÍNEZ ARGÜELLES, S.R. and RUBIERA MOROLLÓN, F. (2000): "Algunas reflexiones acerca de la productividad de los servicios en la economía española". Estudios de Economía Aplicada, 16, pp. 133-155.

MAS, M. and QUESADA, J. (2006): The role of ICT on the Spanish productivity slowdown. Documentos de Trabajo 13, Fundación BBVA.

MINONDO, A. (2007): “¿Cuál es el grado de sofisticación de las exportaciones manufactureras españolas?". Estudios de Economía Aplicada, 25 (3), pp. 643-654.

ORGANIZATION FOR ECONOMIC CO-OPERATION AND DEVELOPMENT (OECD) (2010): OECD Economic Surveys: Spain. Paris.

ORGANIZATION FOR ECONOMIC CO-OPERATION AND DEVELOPMENT (OECD) (2008): Economic Survey of Spain 2008: Fostering competition in product markets to boost productivity. Paris.

ORGANIZATION FOR ECONOMIC CO-OPERATION AND DEVELOPMENT (OECD) (2004): Information, Communication Technology (ICT) Goods, Glossary of Statistical Terms. Paris.

ORGANIZATION FOR ECONOMIC CO-OPERATION AND DEVELOPMENT (OECD) (2003): ICT and Economic Growth: Evidence from OECD Countries, Industries and Firms. Paris.

PORTER, M.E. and VAN DER LINDE, C. (1995): "Towards a new conception of the environment-competitiveness relationship". The Journal of Economic Perspectives, 9 (4), pp. 97-118.

SMITH, D. (1997): "Technology, commodity chains and global inequality: The South Korean case in the 1990s". Review of International Political Economy, 4 (4), pp. 734-762.

TIMMER, M.; O'MAHONY, M. and VAN ARK, B. (2007): "EU KLEMS growth and productivity accounts: An overview". International Productivity Monitor, 14, pp. 71-85.

WEISS, J. (2005): Export Growth and Industrial Policy: Lessons from the East Asian Miracle Experience. Asian Development Bank (ADB) Institute Discussion Paper No. 26

WOLTER, F. (1977): "Factor proportions, technology and West German industry's international trade patterns". Weltwirtschaftliches Archiv, 113, pp. 250267.

WORLD ECONOMIC FORUM (WEF) (2010): The global competitiveness report 2010-2011. Geneva. 


\section{Annex A: An Empirical Analysis of the Determinants of Overall Labour Costs: Wage and Non-Wage Costs}

Section 4 of this paper analysed, among other things, effective wage determination. The section provided additional insights for policy-making through two simulations that illustrated the effects that different inflation and wage policies could have on the growth of labour costs in the future. These simulations were constructed on the base of an econometric analysis estimated to shed light on the various determinants of wage and non-wage costs in Spain and their relative importance. This annex explains how the model was constructed and presents the results of the exercise. The objective of the analysis is to examine the components of overall labour costs - i.e. wage and non-wage costs - in Spain during the decade of booming growth (1998-2008).

Our theoretical starting point is a standard neo-Keynesian macroeconomic model..$^{33}$ In its simplest form, standard neo-Keynesian macroeconomic models of wage/non-wage costs take the shape of a wage-setting equation (also called the wage curve) with the form:

$$
w_{t}=\beta_{0}+\beta_{1} \pi_{t}+\beta_{2} a_{t}-\beta_{3} u_{t}+\beta_{4} \Omega_{t}+\varepsilon_{t}
$$

where, $\pi$ represents prices, $a$ the productivity of labour and $u$ the level of unemployment. Other relevant variables are featured in the vector $\Omega$. In the simplest form of the model, the vector $\Omega$ includes a series of labour market institutional variables, which may differ depending on the labour market realities of the country analysed. ${ }^{34}$ Generally, the model includes a variable that measures the level of unionization of the country as well as the level of replacement incomes or unemployment benefits. There is also a measure of the skill level of workers, and the tax and social contribution wedge (as the difference between incomes received by the worker including social contributions and the cost of labour for the employer). An extended version of this model often includes trade and macroeconomic indicators, such as the terms of trade or even total trade.

\section{A.1. The variables used}

First of all, the model presented in this annex includes for the estimation of wage and non-wage costs the standard variables mentioned above: prices $(\pi)$, productivity $(a)$ and unemployment $(u)$ (Table 1). Although, as it will be seen below, the two latter variables were not retained by any of the two models given

${ }^{33}$ See Blanchard and Katz (1999) and Carnot et al. (2005), for a discussion on the different forms that macro neo-Keynesian models take and explanations of the different explanatory variables that each model adds to take account of a variety of factors.

${ }^{34}$ For simplicity reasons, the analysis assumes that all institutional variables included in the vector $\Omega$ are in their linear. 
their low significance level.

Other variables integrated in the analysis include:

- In the wage costs equation: To take account of labour market institutions, an index that measures the extent of union coverage (uncov) was included as a proxy for the extent of collective bargaining in the country. The terms of trade (trade) measured by the index between the export prices over the import prices, were also included as an explanatory variable.

- In the non-wage costs equation: The measure of union coverage was also included in the non-wage cost determination as well as the average replacement rate (arr). Moreover, given the importance of the average per cent of dismissals (dis), and the share of unskilled workers (uns) in Spain's nonwage costs, the model took them into account as part of the determinants.

Table 1

Definitions and sources of variables used in the regression analysis

\begin{tabular}{|c|c|c|}
\hline Variable & Definition & Source \\
\hline Wages & $\begin{array}{l}\text { Wages and salaries. Nominal value. Index: } \\
2000=100\end{array}$ & Eurostat database \\
\hline Non-wage cost & $\begin{array}{l}\text { Labour cost other than wages and salaries. } \\
\text { Nominal value. Index: } 2000=100\end{array}$ & Eurostat database \\
\hline Inflation & $\begin{array}{l}\text { Annual average of the Consumer Price Index: } \\
2006=100\end{array}$ & $\begin{array}{l}\text { INE (Spanish National Institute } \\
\text { of Statistics) }\end{array}$ \\
\hline Productivity & $\begin{array}{l}\text { Gross Domestic Product per hour worked. } \\
\text { Constant prices. }\end{array}$ & OECD.Stat \\
\hline Unemployment & Unemployment rate. & INE. Labour Force Survey \\
\hline $\begin{array}{l}\text { Average } \\
\text { unemployment } \\
\text { replacement rate }\end{array}$ & $\begin{array}{l}\text { The ratio of an individual's (average) pension in a } \\
\text { given time period and the (average) income in a } \\
\text { given time period* }\end{array}$ & OECD.Stat \\
\hline Union coverage & $\begin{array}{l}\text { The percentage of wage and salaried workers } \\
\text { covered by a collective agreement. }\end{array}$ & ICTWSS database ${ }^{* *}$ \\
\hline Unskilled & Percentage of employees in unskilled occupations. & INE. Labour Force Survey \\
\hline Dismissals & $\begin{array}{l}\text { Average annual number of quarterly dismissals as } \\
\text { a share of the number of employees during the } \\
\text { previous quarter. }\end{array}$ & $\begin{array}{l}\text { Spanish Ministry of Labour and } \\
\text { Immigration }\end{array}$ \\
\hline Terms of trade & $\begin{array}{l}\text { Quotient between Exports price and Imports price. } \\
\text { Index: } 2000=100\end{array}$ & $\begin{array}{l}\text { INE. Statistical Yearbook of } \\
\text { Spain }\end{array}$ \\
\hline
\end{tabular}

* The average gross replacement rate across is measure across two income situations (100 per cent and 67 per cent of APW earnings), three family situations (single, with dependent spouse, with spouse in work) and three different unemployment durations (1st year, 2nd and 3rd years, and 4th and 5th years of unemployment). APW earnings are the estimated full-time earning of an average production worker in a given time period.

** The ICTWSS (Institutional Characteristics of Trade Unions, Wage Setting, State Intervention and Social Pacts) database is provided by the Amsterdam Institute for Advanced Labour Studies (AIAS).

Source: Authors calculations. 


\section{A.2. The model estimated}

Based on this theoretical framework the analysis of the determinants of wage and non-wage costs was carried out using a system of equations in first differences. Unit root tests (through the augmented Dickey-Fuller test and the PhillipsPerron test) were first run to ensure that variables in levels were non-stationary. Moreover, to facilitate the interpretation of the coefficients, the model used the natural logarithm of the first differences. With this in mind, the following specifications of the wage equation (1) and non-wage cost equation (2) were chosen:

$$
\begin{array}{ll}
D \ln (w)_{t}=a_{1}^{w} D \ln \left(p_{t}\right)+a_{2}^{w} D \ln \left(\pi_{t}\right)-a_{3}^{w} D \ln \left(u_{t}\right)+a_{4}^{w} D \ln \left(L M I_{t}\right)+a_{5}^{w} D \ln \left(\text { trade }_{t}\right)+\varepsilon_{t}^{w} & 1 \\
D \ln (n w)_{t}=a_{1}^{n w} D \ln \left(p_{t}\right)-a_{2}^{n w} D \ln \left(u_{t}\right)+a_{3}^{n w} D \ln \left(L M I_{t}\right)+a_{4}^{n w} D \ln \left(\text { diss }_{t}\right)+a_{5}^{n w} D \ln \left(u n s_{t}\right)+\varepsilon_{t}^{n w} & 2
\end{array}
$$

where:

$\pi$ represents prices; $a$, labour productivity; $u$, the unemployment rate; $L M I$, a set of institutional variables; and trade, a set of trade variables. In addition, diss is the share of dismissals in total employees; and uns, the percentage of employees in unskilled occupations.

Moreover, $D$ denotes the first difference or the annual growth rate of the variables. $^{35}$ The estimation of (1) and (2) was done through a Zellner's seemingly unrelated regression, controlled for first-order autocorrelation. It could be argued that wages and non-wage costs are mutually influenced, and that wages influence inflation rates - though not contemporaneously. However, the lack of quarterly data regarding labour market institution indicators constrained the efforts to forgo a simultaneous relation between overall labour cost components, as well as to allow for endogeneity of the inflation rate. Therefore, the results of this model should be interpreted with caution; as being more descriptive of the relationships between variables rather than fully causal.

\section{A.3. The results}

A number of interest results arise from the analysis:

- The model identifies inflation as the principal factor explaining positively and significantly (Table 2 ) both changes in wages and in non-wage costs during the period 1998-2008. In fact, the model illustrates that over this period around 30 per cent of the growth in wages, and more than 21 per cent of the non-wage cost developments were due to rising consumer prices.

${ }^{35}$ Due to the lack of quarterly data on labour market institution indicators, the regression was estimated using annual data from 1997 to 2008, which was the only information available for most of the variables used. 
- Union coverage growth rates have a positive impact on wage and nonwage cost growth rates as well. This is important, but not surprising giving that any improvement in strengthening the bargaining position of workers, ceteris paribus, would have an upward influence on wages and on non-wage costs.

- Regarding other less standard relationships in the specification of the wages equation, the terms of trade show a direct relationship with wage costs. On the contrary, unemployment was shown to be negatively related to wages, which is the standard theoretical relationship: an increase in unemployment would result in a weaker position of workers in collective bargaining and therefore would imply lower wages. However, the level of significance of this variable was not sufficiently high and therefore it was rejected by the model. Another variable that did not appear to be significant as a determinant of wages was productivity. This is not surprising giving that in Spain empirical evidence shows that neither wages nor non-wage costs growth have been in line with productivity growth during the past decade and a half. Nevertheless, future reforms of the labour market in Spain should relax the strong linkage between inflation and wages and use other variables, such as labour productivity as a reference for the determination of wages. ${ }^{36}$

- Additional explanatory variables of non-wage costs also show interesting results. Growth in the average unemployment replacement rate impacts negatively non-wage costs. This is logical if one thinks in terms of the compensatory differences that take place: given the additional protection of a higher replacement rate, further improvements to non-wage costs are no longer necessary. Finally, the share of workers in unskilled occupations and the average share of dismissals both have a positive influence in non-wage costs.

- Regarding the magnitude of the effects, inflation turns to be the variable with the highest impact on both wages and non-wage costs. Indeed, a 1 per cent increase in the inflation rate will translate into a 1.24 per cent increase in wage costs and a 1.22 per cent increase in non-wage costs. Moreover, additional efforts to improve the skill levels of workers and to reduce redundancies will have a positive effect in reducing non-wage costs, although marginally. These results provided the quantitative basis for simulating the policy scenarios presented in section 4 of this chapter.

${ }^{36}$ The body of the paper explains the empirical relationship between wages and productivity in more detail. 


\section{Table 2}

Regression results

\begin{tabular}{lcc}
\cline { 2 - 3 } & $\begin{array}{c}\text { Growth rate of wage } \\
\text { costs (DInw) }\end{array}$ & $\begin{array}{c}\text { Growth rate of } \\
\text { non-wage cost } \\
\text { (DInnwagecost) }\end{array}$ \\
\hline Inflation (DInp) & 1.246 & 1.226 \\
Terms of trade (DIntrade) & $(9.87)^{* *}$ & $(3.94)^{* *}$ \\
\hline Union coverage (DInuncov) & 0.063 & 0.78 \\
Average unemployment replacement rate (DInarr) & $(2.66)^{* *}$ & $(4.93)^{* *}$ \\
\hline Share of workers in unskilled occupations (DInuns) & 0.525 & -0.507 \\
\hline Average percent of dismissals (DIndiss) & $(6.42)^{\star *}$ & $(-5.37)^{* *}$ \\
\hline Constant & & 0.138 \\
& & $(3.39)^{* *}$ \\
\hline
\end{tabular}

Note: All variables are controlled for stationarity. Absolute value of t-statistics (z-statistics in the tests of autocorrelation) in parentheses. Significance levels: *significant at 5 per cent; ** significant at 1 per cent.

Source: Authors calculations. 
